\title{
Reproduction of the deep-water shrimp Aristeus antennatus (Decapoda: Dendrobranchiata)
}

\author{
Montserrat Demestre, José-Manuel Fortuño
}

Institut de Ciències del Mar, Passeig Nacional s/n, E-08039 Barcelona, Spain

\begin{abstract}
Morphology, structure, and function of the reproductive system of the shrimp Aristeus antennatus (Risso, 1816) were investigated using light microscopy and scanning electron microscopy. Monthly samples were taken by trawling on the continental slope $(400$ to $800 \mathrm{~m})$ of the northwestern Mediterranean during 1984, 1985, 1986 and 1989. Sexual characteristics, thelycum, petasma, genital apertures, appendix masculina, and rostrum were considered and possible functions in reproductive behaviour are suggested. The roles of testis, proximal and medial vas deferens regions, and terminal ampulla in hemispermatophore formation were assessed. During mating hemispermatophores join and form a compound spermatophore. The sperm mass in the compound spermatophore was surrounded by 5 layers secreted along the vas deferens duct. Open-type thelycum species with external mating and fertilization such as $A$. antennatus need to develop a complex spermatophore to protect the sperm mass. The structure of sperm was examined for the first time in A. antennatus. The peculiar morphological features of this immobile sperm differ considerably from sperm cells of other decapod groups. It is suggested that this spermatophore formation and sperm structure have taxonomic and phylogenetic value. Spermatogenesis and spermatophore formation divided male gonad development and functionality into 3 stages. Oagenesis can be divided into 6 stages taking into consideration cytological changes in the oocytes. A key to macroscopically identify sexual stages of gonad development which can be used externally on fresh or live specimens is proposed based on the study of gametogenesis and gonad and sexual characteristic development and function.
\end{abstract}

\section{INTRODUCTION}

There is a great deal of experimental scientific literature on commercial coastal species of the suborder Dendrobranchiata due to its importance in aquaculture. Many studies have been made on aspects of artificial feeding, force-feeding and on induction of spawning (Dall et a]. 1990) but little is known of the reproductive biology of these shrimps in the field environment, and even less when dealing with deepwater species, with Mediterranean species being the least known of all (Dall 1991). The 'gamba shrimp' Aristeus antennatus (Risso, 1816) is an exploited species which plays an important role in the overall biomas of the muddy bottoms of the slope 1400 to $2000 \mathrm{~m}$ ) in the Northwestern Mediterranean (Cartes \& Sardà 1989, Demestre 1990).

An initial general description of the secondary sexual characteristics and development of genitalia in both sexes of Aristeus antennatus was given by Heldt (1938). Subsequent studies have increased knowledge on reproduction of this species (Relini Orsi \& Relini 1979, Arrobas \& Ribeiro Cascalho 1987, Orsi Relini \& Tunesi 1987, Sardà \& Demestre 1987, Demestre 1990). However, many aspects of its reproductive biology are still largely unknown, as is the case with many other exploited species, in spite of this being indispensable information for subsequent assessment and management studies of its fishery

The main objective of this study was thus to achieve a thorough understanding of the biology and dynamics of reproduction in this species. Different processes related to changes in the structure, morphology and functionality of the reproductive system, in both females and males, of Aristeus antennatus were studied throughout the maturation process. For the first time, a scanning electron microscopy image of its sperm is presented. Detailed study of ovary development and 
formation of the spermatophore enabled the drawing up of an external identification key to the different stages of gonad development, supported by histological evidence. Study of the different layers forming the spermatophore revealed differences in spermatophore formation and structure between Dendrobranchiata and Pleocyemata decapods. These data shed new light on the phylogeny of both decapods in general and Dendrobranchiata species in particular.

\section{MATERIALS AND METHODS}

Field sampling. A total of 7627 females and 2821 males of Aristeus antennatus were collected by commercial bottom-trawl gear off the Catalan coast (northwestern Mediterranean) (Fig. 1), from samplings carried out in 1984,1985, 1986 and 1989 at fortnightly or monthly intervals. In each sample, some 150 individuals of both sexes were collected at random from landings from muddy bottoms of submarine canyons on the slope, at between 400 and $800 \mathrm{~m}$ depth. These were kept fresh and transported to the ldboratory, where biological analysis was performed. Sex, carapace length, presence or absence of the spermatophore in the thelycum of females, wet body weight and wet gonad weight were recorded. Spermatophores from the thelycum of females and hemispermatophores from the terminal ampulla of the vas deferens of males were removed and examined for gross appearance, and histological preparations and squash mounts made to determine the presence of spermatozoa and to study secretion of the different layers making up the spermatophore. Gonad development was determined from gross observations and validated by histology, using both light and scanning electron microscopy. External sexual characteristics, first pleopods, thelycum, appendix masculina and genital apertures were examined in both juvenile and adult specimens.

Light microscopy (LM). Fresh material for examination under LM was fixed with Bouin's solution, dehydrated in an ascending isopropilic series, embedded in paraffin (melting point $=56^{\circ} \mathrm{C}$ ) and serially sectioned at 4 to $8 \mu \mathrm{m}$. Hematoxylin-eosin (Hansen's hematoxylin and Heidenhein's hematoxylin) and Mallory were used as topological stains. Hematoxylin-picrofuchsin (Van Gieson's trichrome, Groat's hematoxylin) and Alcian Blue-Pas were the specific stains used.

Squash preparations. Fresh material for examination under light microscopy was rubbed over a slide previously cleaned in alcohol and stained by the 'Diffquick' method (Durfort 1978, Gosàlbez et al. 1979). For observation with scanning electron microscope, the process was the same as outlined above (Felgenhauer 1987).

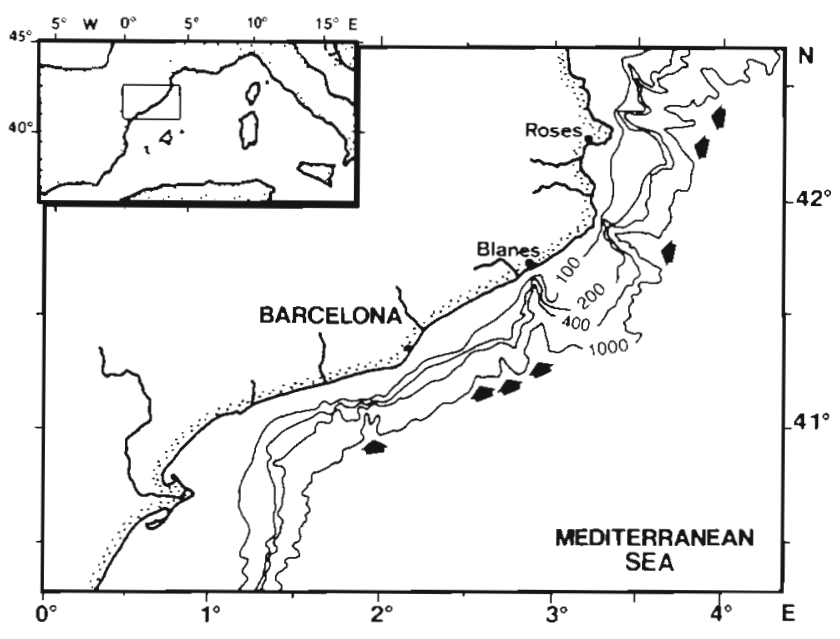

Fig. 1 The Catalan coast in the northwestern Mediterranean. Arrows indicate the submarine canyons

Scanning electron microscopy (SEM). Material for examination under SEM was dissected from fresh specimens and methods described by Felgenhauer (19人ô) were empluyed: fixed using $3 \%$ giutaraldehyde buffered in filtered sea-water $(12 \mathrm{~h})$ and post-fixed in $2 \%$ osmium tetroxide $(1 \mathrm{~h})$, dehydrated in an ascending ethanol series to amyl acetate, critical point dried using $\mathrm{CO}_{2}$, sputter-coated with gold-palladium. The material was then viewed with a Hitachi S-570 scanning electron microscope operated at $15 \mathrm{kV}$.

\section{RESULTS}

\section{Sexuality and morphology}

Sex determination of Aristeus antennatus was externally possible from secondary sexual characteristics and the different location and morphology of gonads in the sexes, even in juvenile specimens.

Females have an open thelycum lacking seminal receptacles. It is a small cavity whose morphology is adapted to attachment of the spermatophore. It is broad, fairly shallow, somewhat quadrangular in shape, and bound by a triangular protuberance of sternite XIII and by 2 small lateral protuberances and a posterior one of sternite XIV. It displays a large number of spines and setae which contribute to firm attachment of the spermatophore. SEM enabled a comparison of the thelycum. of juvenile and adult females. In both, the basic configuration is the same, although in adults the spines and setae obscure the functional shape and dimensions (Fig. 2)

The petasma in males is a laminar modification of the endopod of the first pleopods, each one representing a hemipetasma. SEM studies revealed that the 2 hemi- 

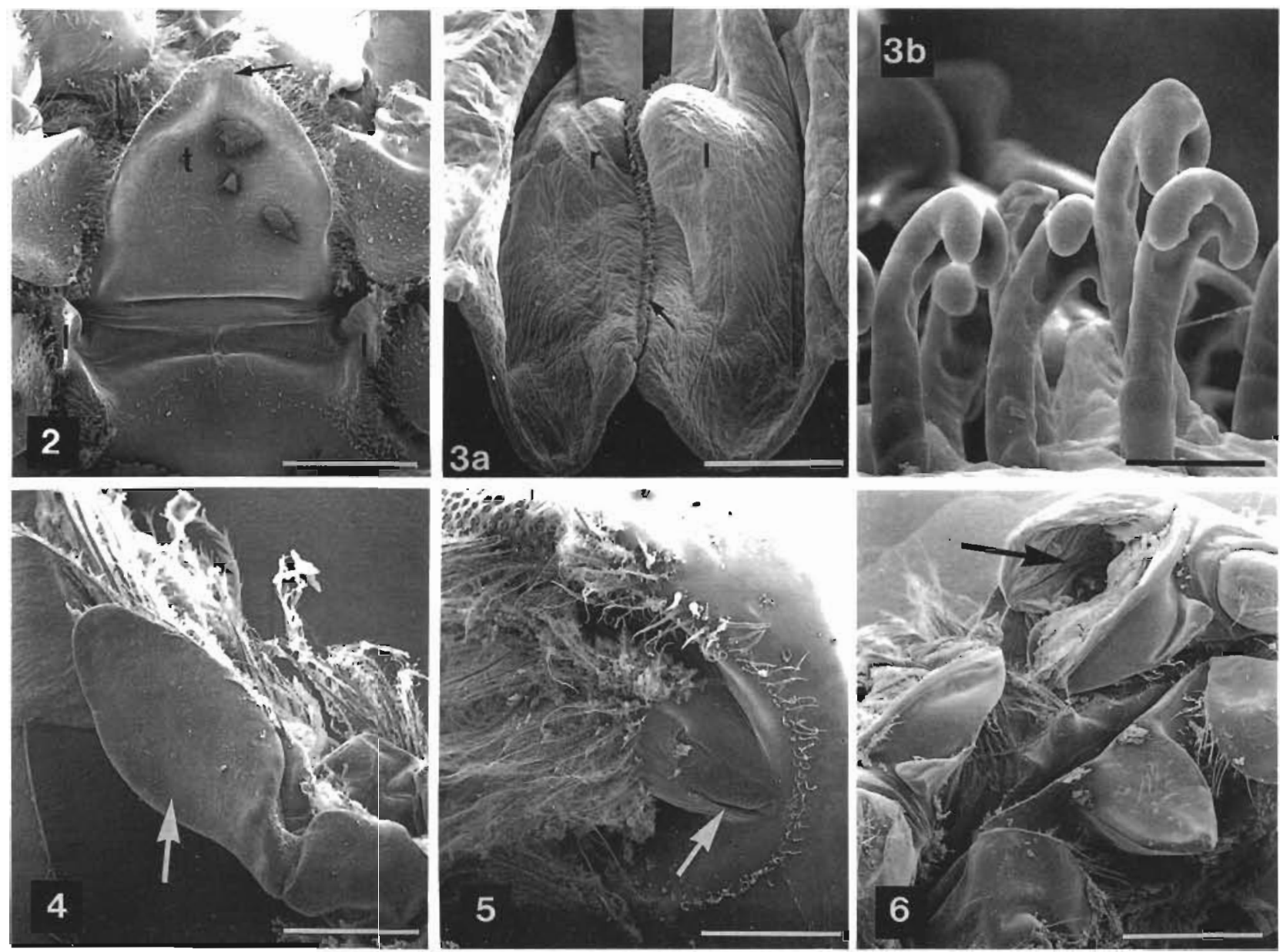

Figs. 2 to 6. Aristeus antennatus. SEM views of secondary sexual characteristics. Fig. 2. Ventral view of the thelycum of a juvenile female showing the triangular protuberance (t) and the 2 small lateral protuberances (1). Note the scarcity of spines and setae (arrow). Scale bar $=1.20 \mathrm{~mm}$. Fig. 3. Petasma of adult male. (a) View of the 2 joined endopods ( $\mathrm{r}$, right; l, left) of the first pleopods that form the petasma. Note the meshed 'cincinnuli' (arrow). Scale bar $=0.81 \mathrm{~mm}$. (b) Detail of the anchor shape of the 'cincinnuli' Scale bar $=30 \mu \mathrm{m}$. Fig. 4. Appendix masculina (arrow) of adult male. Scale bar $=0.75 \mathrm{~mm}$. Fig. 5 . Female genital aperture (arrow) located on the coxae of the third pereiopod. Scale bar $=0.43 \mathrm{~mm}$. Fig. 6. Male genital aperture (arrow) located on the coxae of the fifth pereiopod. Scale bar $=1.50 \mathrm{~mm}$

petasmas join at internal lobe level, by means of a characteristic structure ('cincinnuli') composed of anchoriform parts interlinking in several strings (Fig. 3a, b). SEM observations showed the same basic structure of the petasma for both juvenile and adult males, although the 2 hemipetasmas were separated in the juveniles.

The appendix masculina of males and genital apertures and rostrum of both sexes are other external structures related to the sex. The appendix masculina is a modification of the base of the flagellum of the endopod of the second pleopod which forms a small, flat triangular lobe (Fig. 4). It is only developed in adult males. The gonopore in females is found on the coxae of the third pereiopods (Fig. 5), while in males it opens on the fifth pereiopods (Fig. 6). In juveniles of both sexes, the genital apertures were found to be already formed. The rostrum differentiates between males and females once sexual maturity has been reached. In males it undergoes spectacular reduction, while in females it is always long and stiletto-like (Sardà \& Demestre 1989).

\section{Functional structure of the reproductive system}

\section{Males}

To achieve an understanding of male reproductive system it is necessary to investigate spermatogenesis and spermatophore formation. The male reproductive tract which is located solely in the thoracic region, consists of paired testes and vasa deferentia. Each vas 
deferens extends from the testis towards the gonopore. It comprises 3 morphologically distinct regions: the proximal portion, narrow and between 4 and $6 \mathrm{~mm}$ in length; the medial portion, thickened and between 9 and $12 \mathrm{~mm}$ in length; and the terminal ampulla, a pearshaped dilation of 2 to $4 \mathrm{~mm}$ long, located on the coxae of the fifth pereiopods, where the gonopore is found

In mature adults, the testicular lobes, composed of connective tissue, have all the germinative cells at the same stage of development (Fig. 7a). Mature specimens occur all year round, with an increase between April and September (Demestre 1990). In juveniles, on the other hand, the testis is not yet structured in lobes and the germinal cells found within the testes are at various stages of maturation. The spermatogonia are located peripherally on the testes, usually near the seminiferous duct, while the strongly acidophilic spermatids are nearer the centre.
Envelopment of the sperm mass by different layers of noncellular materials is initiated in the proximal and medial portion of the vas deferens, and continues until complete formation of the hemispermatophore, which is found on the terminal ampulla.

Spermatophore formation. A serial transverse section through the entire length of the vas deferens revealed that on its outer part there is always a thin layer of connective tissue which surrounds a columnar epithelium secretor of prismatic cells. Transverse sections of the first part of the proximal portion of the vas deferens, where there was great secretory activity, confirmed the presence of sperm mass. On this level it is possible to observe the typhlosolic invagination, a highly active secretory structure. This typhlosole divides the lumen of the vas deferens into 2 independent, unequal sections. In that of smaller diameter, the epithelial typhlosole cells secrete a

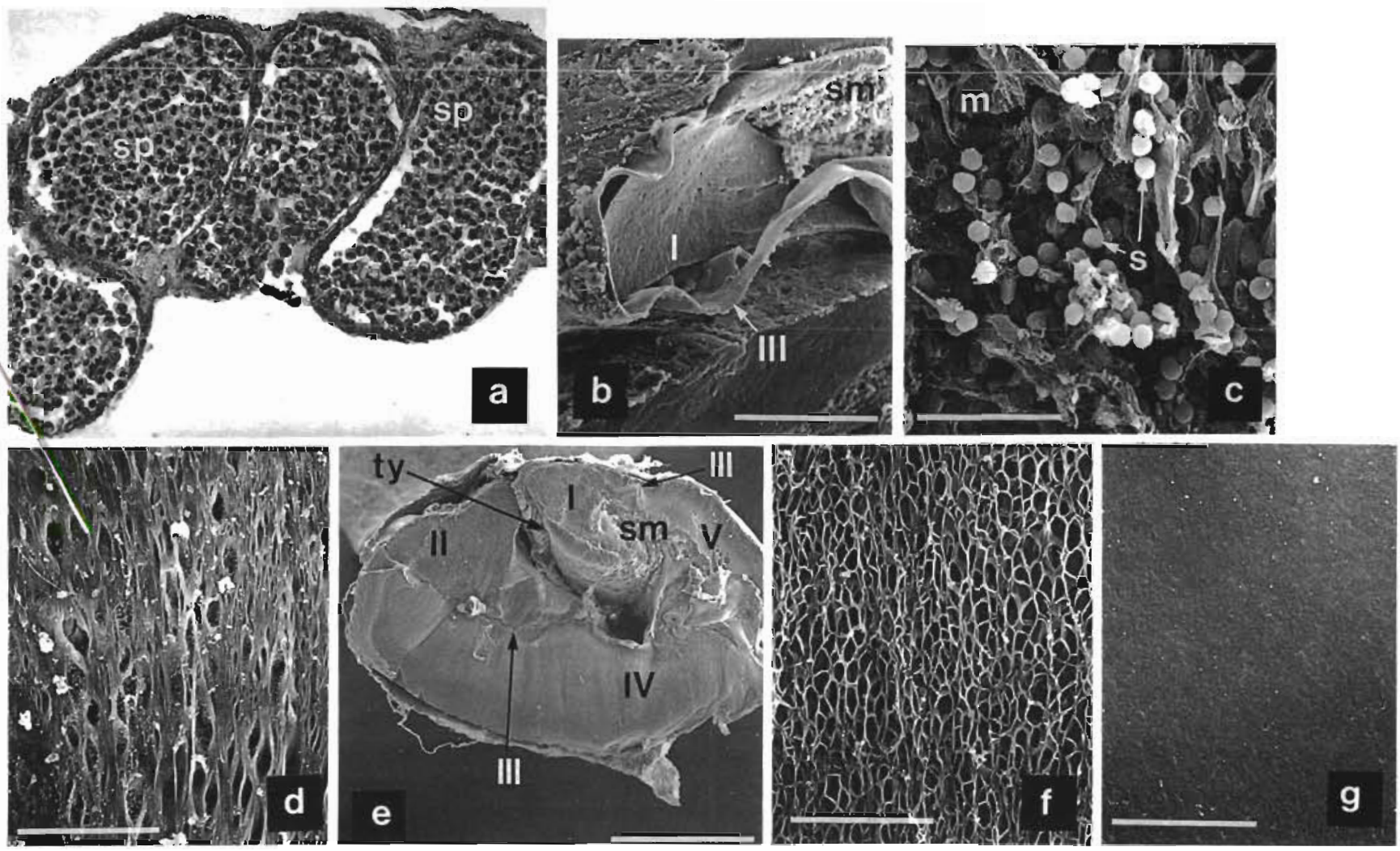

Fig. 7. Aristeus antennatus. Adult male reproductive system. (a) Histological paraffin section through testes which contain numerous spermatids (sp). LM; Groat hematoxylin stain; $\times 270$. (b) to (g) Medial vas deferens (SEM). (b) Low magnification image of primary layer (I), sperm mass (sm) and third layer (III). Scale bar $=88 \mu \mathrm{m}$. (c) Detail of sperm mass illustrating the sperm (s) and the fibrous sperm matrix $(\mathrm{m})$. Scale $\mathrm{bar}=15 \mu \mathrm{m}$. (d) Detail of secondary layer (II) with fibrous and collapsable structure. Scale bar $=1.5 \mu \mathrm{m}$. (e) Transverse section of medial portion of vas deferens. This portion consists of the distal end of the detached typhlosolic invagination (ty) and fourth layer (IV) penetrating between the 2 sections of the vas deferens. Sperm mass (sm) is surrounded by primary layer (I). Third layer (III) is deposited around primary (I) and secondary (II) layers. Fourth (IV) and fifth (V) layers are located in distal region of vas deferens, protecting the sperm mass. Scale bar $=0.43 \mathrm{~mm}$. (f) Detail of fourth layer (IV) revealing its 'corky' appearance. Scale bar $=15 \mu \mathrm{m}$. (g) Detail of the homogeneous and uniform aspect of the fifth layer ( $V$ ). Scale bar $=15 \mu \mathrm{m}$ 
strongly basophilic noncellular substance, the primary layer (I) (Fig. 7b), which is deposited around the sperm mass (Fig. 7b, c). In the other, larger section of the vas deferens, another noncellular substance, the secondary layer (II), was secreted simultaneously. This layer, less basophilic, comprises the wing portion, or protective element of the future compound spermatophore. Under SEM this layer appeared fibrous and collapsable (Fig. 7d). Another noncellular substance, the third layer (III), was secreted from the innermost side of the typhlosole. Under LM, this layer appeared glassy and greenish-yellow when stained with hematoxilin-eosin. Under SEM it was laminate (Fig. 7b). This layer III is always thin and surrounds the other layers like a 'border'. In this section of the vas deferens it only begins to surround layer II on its outermost part, and layer I slightly on both sides. Serial transverse sections at about $3500 \mu \mathrm{m}$, of this portion showed layer I already completely surrounded by layer III, and layer II only surrounded on its external side.

At the start of the medial portion of the vas deferens, at about $700 \mu \mathrm{m}$, a new noncellular basophilic substance, the fourth layer (IV), is secreted adjacent to layer II, or else flows into the 2 sections of the vas deferens due to the typhlosole detachment (Fig. 7e). Under SEM this layer IV showed a 'corky' and reticulate appearance (Fig 7f). Under LM it took on a brownish-yellow tone with van Gieson hematoxylinpicrofuchsin. In this portion of the medial vas deferens, at some $6300 \mu \mathrm{m}$ from the previous zone, the last noncellular substance, the fifth layer (V), was secreted by the columnar epithelium secretor. It is a basophilic layer of uniform and homogenous aspect under both LM and SEM (Fig. $7 \mathrm{~g}$ ).
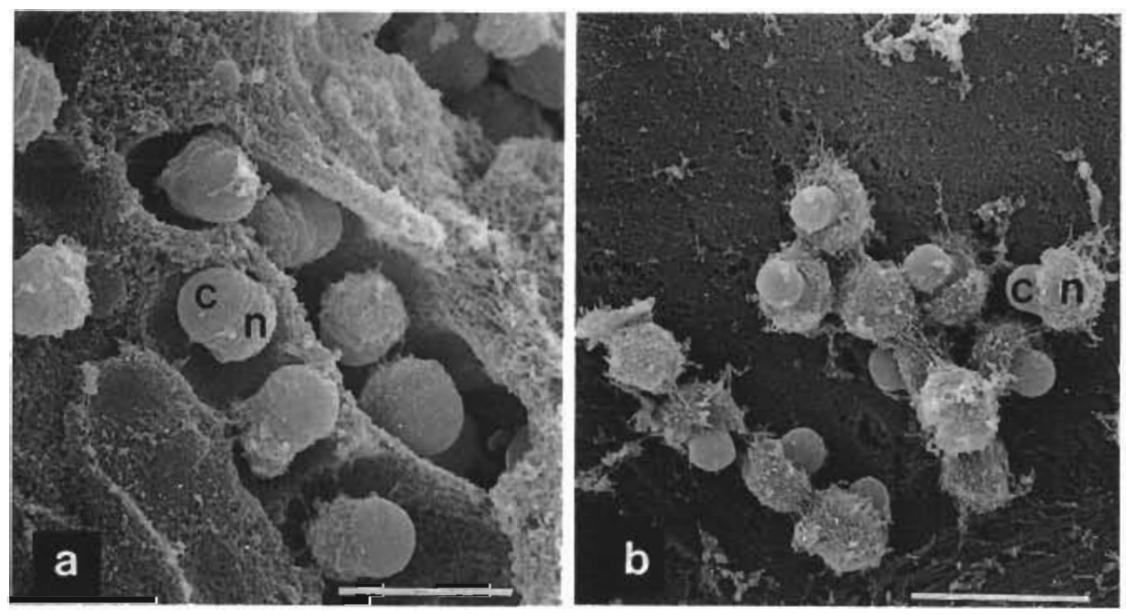

Fig. 8. Aristeus antennatus. SEMs of the aflagellate spermatozoa showing the cap (c), an electro-dense substance, and the nucleus (n), a flocculent substance. (a) From hemispermatophore. Scale bar $=5 \mu \mathrm{m}$. (b) From spermatophore. Scale bar $=10 \mu \mathrm{m}$
On the terminal ampulla, the layers attain their maximum dimension until a hemispermatophore forms on each one. The compound spermatophore is formed during mating when each of the paired terminal ampullae expel their hemispermatophores and the two unite and form the spermatophores which is deposited on the open-type thelycum of the female.

Sperm morphology. SEM studies of the hemispermatophore revealed the sperm mass, from which it was possible to obtain images of individual spermatozoa. Such images show a clearly aflagellate structure composed of 2 well-differentiated bodies, one main body spherical, consisting of an electro-dense substance, the cap, and the other a flocculent substance, the nucleus. No appendages or radiating spikes are present. The sperm are non-motile. Dimensions varied from 2 to $3 \mu \mathrm{m}$ (Fig. 8a).

Squash preparations of fragments and sections of the spermatophores (taken from the thelycum), treated for SEM observation, revealed the spermatozoon, covered by the fibrous sperm mass, with the same basic aflagellate structure, without spikes and composed of 2 bodies, one electro-dense and the other flocculent. Dimensions varied from 3 to $4 \mu \mathrm{m}$ (Fig. $8 \mathrm{~b}$ ). Squash preparations of the spermatophores for LM also showed the same aflagellate images, appearing in the form of 2 spherical shapes without spikes. Stained with 'Diff-Quick', one, the cap, was deeply blue-violet and the other, the nucleus, refringent-whitish.

\section{Females}

The reproductive tract of females comprises a symmetrical 2-lobed ovary along the longitudinal axis of the shrimp. There are 3 distinct sections: cephalic, thoracic and abdominal. The ovary varies in size and colour throughout one complete cycle of oocyte maturation. The functional activity of the ovary is evident from May to September, with a maximum in June, July and August. In early May the previtellogenesis phase begins. The exogenous vitellogenesis phase occurs until the end of September. The results obtained throughout the 4 years studied were consistent, regardless of location.

The parenchyma ovary is shaped into lobes divided by septa, within which the oocytes are arranged mosaic-like. The 

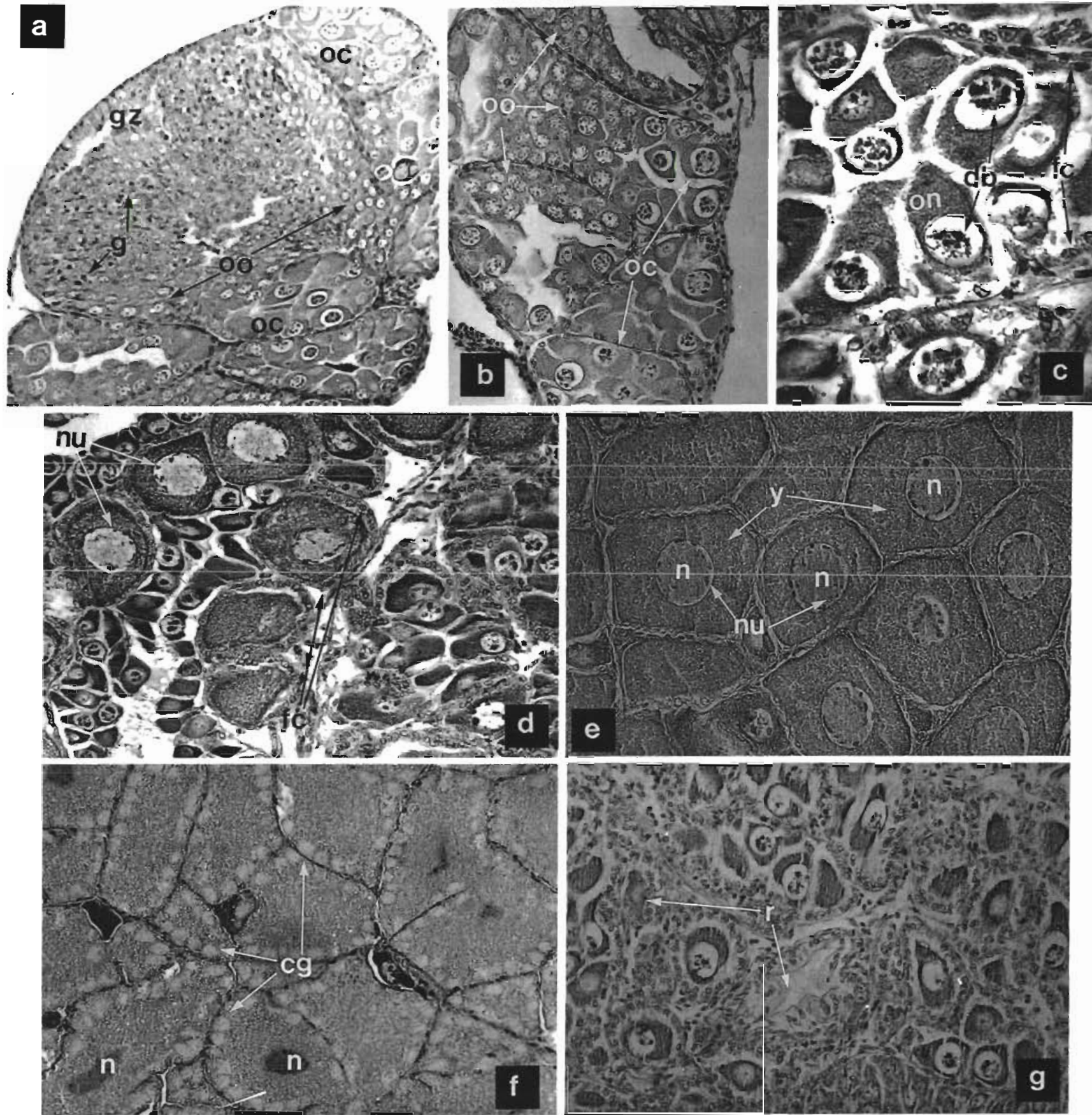

Fig. 9. Aristeus antennatus. Oogenesis. (a) Proliferative phase. Histological paraffin section showing primordial gonias (g) and oogonial cells (oo) grouped in the germinative zone (gz), and early primary oocytes (oc) radiating out from germinal zone. Hema toxylin (H) \& eosin (E) stain; $\times 63$. (b) Detail of the oogonia cells (oo) and early primary oocytes (oc). Groat's $\mathrm{H}_{i} \times 190$. (c) Meiosis phase. Enlarged detall of chromatin nucleolus stages oocytes (on) exhibiting dense bodies (db). Note the follicle cells (fc). $\mathrm{H} \& \mathrm{E}$ stain; $\times 400$. (d) Previtellogenesis phase. Oocytes with peripheral nucleoli (nu) and follicle cells (fc) surrounding oocytes. Hansen's H \& E stain; $\times 190$. (e) Early secondary vitellogenesis phase. Oocytes with accumulated yolk globules (y) in the ooplasma and still prominent nucleus ( $\mathrm{n}$ ) with several peripheric nucleoli (nu). They acquire a polyedral shape. Hansen's H \& $\mathrm{E}$ stain; $\times 270$. (f) Late secondary vitellogenesis phase. Follicle cells have disappeared. Oocytes showing shrunken and migrated nucleus (n) and peripheric cortical granules $(\mathrm{cg})$. Groat's $\mathrm{H}_{3} \times 270 .(\mathrm{g})$ Oosorption phase. Ovary section showing a irregular shape 
cytological changes presented by oocytes in one complete cycle of ovarian maturation enabled the separation of oogenesis into 5 phases: proliferative phase, meiosis phase, previtellogenesis phase, vitellogenesis phase (endogenous and exogenous), and oosorption phase.

Proliferative phase. During proliferation in the ovary a large number of the primordial gonia and oogonial cells start dividing. They are found grouped in the germinal zone (Fig 9a), and can be observed at all stages of maturation of the ovary, located in more or less peripheral zones, above all in juvenile females. The germinal cells are strongly basophilic. The oogonial cells ( 6 to $16 \mu \mathrm{m}$ in diameter) have a large nucleus and a small amount of ooplasm. In the nucleus, patches of clumped peripheral chromatin can be seen (Fig. 9b).

Meiosis phase. In the meiosis phase, the primary oocytes (16 to $24 \mu \mathrm{m}$ in diameter) continue forming groups of various cells and remain very close to the germinative zone. They are referred to as oocytes with visible chromosome and can be seen completely immersed in the follicle. The nucleus of these oocytes continues to be very large, taking up almost all the cellular volume, with uniformly distributed chromatin. Different meiotic stages are observed inside the nucleus (Fig. 9c). The cytoplasm is weakly basophilic.

Previtellogenesis phase. The oocytes enter a rapid growth stage. Their dimensions at the start of this phase vary between 32 and $53 \mu \mathrm{m}$, and they have a totally irregular shape, almost always acquiring an external amoeboid form. They subsequently increase in size, to between 63 and $95 \mu \mathrm{m}$, and their shape becomes more regular. Nucleoli in varying numbers begin to be differentiated, and undergo migration as previtellogenesis progresses, positioning themselves on the peripheral area of the nucleus (Fig. 9d). Both ooplasm and nucleoli were strongly basophilic. As this phase progresses, the previtellogenetic oocytes migrate towards more peripheral areas of the ovary. By the end of this phase, the basophilic follicular cells ( $5 \mu \mathrm{m}$ in diameter) are already clearly visible around the oocytes. It is these that form the ovarian follicle.

Endogenous vitellogenesis phase (primary vitellogenesis). The oval oocytes ( 84 to $126 \mu \mathrm{m}$ in diameter) are already clearly located in the periphery of the ovary. The nucleus continues to be central, reaching its maximum volume, with a diameter of about $40 \mu \mathrm{m}$, and a much more compact shape. Inside it, 4 to 6 spherical nucleoli appear, located near the nuclear membrane. For the first time, vitellin platelets are observed in the ooplasm which cause it to lose compactness. They are endogenous in origin (autosynthesis). In this phase, the oocytes (90 to $100 \mu \mathrm{m}$ in diameter) appear more individualised, acquire a polyhedral shape and seem superimposed on each other. The follicular cells measure between 7 and $9 \mu \mathrm{m}$ in diameter.
Exogenous vitellogenesis phase (secondary vitellogenesis). Divided into early and late vitellogenesis, this occurs when new vesicles from the micropinocytosis process appear They are acidophilic vesicles and stain positively with Sudan Black B, confirming that they are lipoproteic structures. Oocytes at the beginning of this phase are rectangular in form, with maximum diameters of 116 to $210 \mu \mathrm{m}$ and minima of 75 to $95 \mu \mathrm{m}$ (Fig. 9e). Once vitellogenesis is over they reach maximum diameters of 168 to $336 \mu \mathrm{m}$ and minima of 81 to $113 \mu \mathrm{m}$. They appear completely stuck to one another, forming a mosaic pattern. The nucleus loses its spherical aspect, decreasing in size and with an irregular profile, and slowly begins to migrate to more peripheral zones of the oocyte, as a result of the fusion of small vitelline platelets. It finally positions itself in areas near the cellular cover, being barely visible. In successive stages of this phase, the follicular cells decrease in size and the follicle becomes completely carpeted by vitellogenetic oocytes, although at intervals some previtellogenetic oocytes and small germinative zones appear. On the periphery of the oocyte, cortical granules appear, which have not previously been described for Aristeus antennatus. These cortical granules tend to be acidophilic in nature. Their dimensions are 15 to $17 \mu \mathrm{m}$ long by 10 to $12 \mu \mathrm{m}$ wide (Fig. 9f). Oocytes with these cortical structures are those that can be considered ready for spawning. Follicular cells are no longer found around these oocytes.

Oosorption phase. In the follicle, it is not uncommon to observe oocytes which, once vitellogenesis is over, have not been expelled from it (Fig. 9g). These oocytes are not functional. They have an irregular shape and gradually decrease in size. Finally they undergo a process of phagocytosis. These resorptive oocytes are comparable to those normally found in the ovary of mammals.

\section{Macroscopic identification of reproductive maturation stages}

On the basis of the findings for oogenesis, a macroscopic scale of ovary maturation has been established, relating morphology and external coloration of the ovary to development and functionality of oocytes. Thus 7 stages of ovary maturation have been characterised (Table 1). For males, a macroscale of maturation has also been established, comparing results of spermatogenesis and formation and functionality of the hemispermatophore with functional structure of the sexual characteristics and gross anatomy of the reproductive tract. Three stages of maturation have been established (Table 1). However, some males, 
Table 1 Aristeus antennatus. Macroscale identification of the gonad maturation comparing gross anatomy, function and gametogenesis

\begin{tabular}{|c|c|}
\hline $\begin{array}{l}\text { (a) Females } \\
\text { Oogenesis phases }\end{array}$ & Stages of female reproductive cycle and ovary functional state \\
\hline $\begin{array}{l}\text { Proliferation phase } \\
\text { (oocytes } 6 \text { to } 16 \mu \mathrm{m})\end{array}$ & $\begin{array}{l}\text { Stage I. Undeveloped (juvenile) } \\
\text { Ovary translucent, extremely thin }\end{array}$ \\
\hline $\begin{array}{l}\text { Meiotic phase } \\
\text { (oocytes } 16 \text { to } 24 \mu \mathrm{m} \text { ) }\end{array}$ & $\begin{array}{l}\text { Stage II. Undeveloped (juvenile) } \\
\text { Resting (adult) } \\
\text { Ovary white-opaque, tubular appearance }\end{array}$ \\
\hline $\begin{array}{l}\text { Previtellogenesis phase } \\
\text { (oocytes } 32 \text { to } 95 \mu \mathrm{m} \text { ) }\end{array}$ & $\begin{array}{l}\text { Stage III. Developing (adult) } \\
\text { Ovary pink-orange, slightly thicker appearance than stage II }\end{array}$ \\
\hline $\begin{array}{l}\text { Primary vitellogenesis } \\
\text { (oocytes } 90 \text { to } 100 \mu \mathrm{m} \text { ) }\end{array}$ & $\begin{array}{l}\text { Stage IV. Maturation (adult) } \\
\text { Ovary light-lilac, turgid and swollen appearance }\end{array}$ \\
\hline $\begin{array}{l}\text { Early secondary vitellogenesis } \\
\text { (oocytes } 116 \text { to } 210 \mu \mathrm{m} \text { ) }\end{array}$ & $\begin{array}{l}\text { Stage V. Advanced maturation (adult) } \\
\text { Ovary lilac, very turgid, occupying large part of dorsal surface }\end{array}$ \\
\hline $\begin{array}{l}\text { Late secondary vitellogenesis } \\
\text { (oocytes } 168 \text { to } 330 \mu \mathrm{m} \text { ) }\end{array}$ & $\begin{array}{l}\text { Stage VI. Spawning (adult) } \\
\text { Ovary purple, very turged, occupying whole of dorsal surface }\end{array}$ \\
\hline Oosorption & $\begin{array}{l}\text { Stage VII. Post-spawning (adult) } \\
\text { Ovary ivory with lilac traces, rapid volume decrease, very flacid }\end{array}$ \\
\hline $\begin{array}{l}\text { (b) Males } \\
\text { Spermatogonosis phases }\end{array}$ & Stages of male reproductive ryrle and testis functional state \\
\hline Spermacytogenesis & $\begin{array}{l}\text { Stage I. Undeveloped (juvenile) } \\
\text { Testes translucent, extremely thin, translucent whitish vas deferens, } \\
\text { filiform appearance }\end{array}$ \\
\hline Spermiogenesis & $\begin{array}{l}\text { Stage II. Undeveloped (juvenile) } \\
\text { White-opaque teste, ivory vas deferens, tubular appearance, without } \\
\text { hemispermatophore in terminal ampulla. Separated hemipetasmas }\end{array}$ \\
\hline & $\begin{array}{l}\text { Stage III. Developed and mature (adult) } \\
\text { Same appearance than stage II with terminal ampulla. Joined hemipetasmas }\end{array}$ \\
\hline
\end{tabular}

which had no hemispermatophores in the terminal ampulla and were therefore immature according to the established macroscale, displayed a joined petasma (proof of having reached sexual maturity). Serial microscopic observations of the vas deferens of these males showed that the sperm mass and all layers making up the hemispermatophore were already present in the middle region of the vas deferens. Structurally and morphologically, the testis is like that of mature males. It seems, therefore, that all that such males lack in order to achieve reproductive functionality is the ability to pass the hemispermatophore to the terminal ampulla.

\section{DISCUSSION AND CONCLUSIONS}

In Aristeus antennatus, petasma and thelycum should act in synchrony during mating, transporting and sustaining the spermatophore until fertilisation. The morphology and functional structure of these 3 elements implies an intimate relationship in the repro- ductive dynamics. This process appears generalised in all Dendrobranchiata species which have an open thelycum without seminal receptacles (Heldt 1938, Palombi 1939, King 1948, Tuma 1967, Pérez Farfante 1969, 1975, 1988, Primavera 1979, De Freitas 1985, Orsi Relini \& Tunesi 1987). Some authors even report having observed this process in different species: Parapenaeus longirostris (Heldt 1932), Sergestes similis (Genthe 1969) and Aristeus varidens (Burukovsky 1978). In decapod species in which females display seminal receptacles, the function of the petasma is clearly that of a copulatory organ (Heldt 1932, Tirmizi 1968, Hartnoll 1969, Diesel 1989).

At the moment of mating, both hemispermatophores are expelled from the terminal ampulla by means of muscular contraction, through the corresponding gonopore. The shape of the 2 hemispermatophores is identical, both of them having the sperm mass surrounded by the various protective layers. Bearing in mind that the coupling process takes place quickly (Demestre unpubl.), it may be inferred that definitive fusion takes place in the thelycum of the female, at the 
same time as the different layers harden. Some authors consider that hardening takes place on contact of the noncellular substances with seawater (Heldt 1932, Tuma 1967, Primavera 1979). However, in the histological studies carried out here, the hemispermatophores already was found to acquire some degree of hardness along the vas deferens, in agreement with Malek \& Bawab (1974a).

Studies of spermatogenesis on a structural and ultrastructural level carried out on crustacean species of different taxonomic groups (King 1948, Genthe 1969, Malek \& Bawab 1974 a, b, Aiken \& Waddy 1980, Johnson 1980, Durfort et al. 1985, García Valero 1988), have led to the finding that the process is basically similar in all the species. However, formation of the spermatophore in decapods does not always follow the same process, nor is the functional structure the same. In Aristeus antennatus and other Dendrobranchiata (King 1948, Genthe 1969, Malek \& Bawab 1974a, b, Chow et al. 1991), the number of layers secreted during the formation of the compound spermatophore is higher than in other Pleocyemata decapods (Dougherty et al. 1986, Beninger et al. 1988, Chow 1989, Diesel 1989). This structural differentiation is of great taxonomic, phylogenetic and evolutionary interest. Open-type thelycum Dendrobranchiata species, which present totally external mating and fertilization phenomena, develop greater complexity in the formation of the spermatophore to protect the sperm mass as efficiently as possible. In the closed-type thelycum species (Penaeus aztecus, $P$. duororum, $P$. monodon, $P$. merguiensis, $P$. indicus) the fibrous layer serves to plug the slits of the thelycum, and disappears shortly after mating (Cummings 1961, Aquacop 1975, Emmerson 1980, Chow et al. 1991). From the evolutionary viewpoint, these differences are of great interest due to their importance in preadaptive mechanisms for transition from aquatic to terrestrial life: within the aquatic organisms which develop spermatophores to transfer the sperm mass, the most highly evolved are those that effect direct transfer to the female with mating and fertilization through gonopods with improper copulatory organs (Schaller 1979). The most advanced case is that of Brachyura, which transfer the sperm packet right into the seminal receptacle, and display successful terrestrial adaptation.

Spermatozoa of crustaceans are highly polymorphic. In decapods they have lost the flagellum and, therefore, their motility. In Mystococarida, Cirripeda and Branchiura, apart from copepods, flagellated forms do exist (Adiyodi 1985, Jamieson 1991). Pochon-Masson (1983) describes the spermatozoa of decapods as generally spherical or cylindrical, non-mobile forms, with a more or less pronounced extension. This author states that the Natantia decapods have retained origi- nal nail-shaped spermatozoa, in contrast to the stellated shape, with radial arms, of the Reptantia.

Spermatozod of Aristeus antennatus examined by SEM in the present study did not show the characteristic structure of the spiked sperm described in other Dendrobanchiata and Natantia in general (indiscriminately referred to as shrimps or prawns) (Jamieson 1991), although the majority of them belong to the group of species with closed-type thelycum (King 1948, Tuma 1967, Genthe 1969, Talbot \& Summers 1978, Kleve et al. 1980, Pochon-Masson 1983, Clark et al. 1984, Dougherty et al. 1986, Dougherty \& Dougherty 1989). The basic sperm structure of $A$. antennatus resembles the general sperm structure of spiny lobster (Panulirus spp.) (Talbot \& Summers 1978) but differs in the presence of the radial arms emanating from the nucleus. The spermatozoa of $A$. antennatus seem to be intermediate between the Reptantia and Natantia patterns.

In the majority of decapod species, it is thought that spermatozoon formation takes place in the testes. However, various stages of spermatozoon maturation must be differentiated until they reach their maximum functional capacity. In the present study, spermatozoa found in the hemispermatophore (terminal ampulla), display a different maturation stage to those found in the spermatophore (thelycum). The functional of the terminal ampulla is clearly connected to maturation of spermatozoa (Chow et al. 1991). In other species, such as Inachus falangium (Diesel 1989), it was found that mature spermatozoa are formed in the medial portion of the vas deferens.

Studies using transmission electron microscopy (Demestre \& Durfort unpubl.) will allow an understanding of the ultrastructure of Aristeus antennatus spermatozoa, as well as determining the development of their maturation stages and finally their capacity to fertilise oocytes. The most important investigations carried out on this last aspect relate to Sycionia ingentis (Clark et al. 1984, Pillai \& Clark 1987), in which the in vitro spermatozoon reaction at the moment of fertilization was studied. The morphology and functional structure of $A$. antennatus sperm described in this paper will also contribute data on the evolutionary process of Dendrobranchiata, perhaps one of the least-known decapod groups as a whole.

Acknowledgements. The authors are grateful to Dr M. Durfort for her support and valuable suggestions, to Dr F. Sardà for his help and useful comments during the research phase of this study, and to Dr P. Abello for his constructive reading of the manuscript. Thanks are also extended to $\mathrm{Mr} \mathrm{M}$. Marhuenda for his help in field work and to Mr J. Biosca for the photographic assistance. This work was partly supported by the Commission of the European Communities (D. G. XIV) and by grants from the CIRIT (Generalitat de Catalunya) and the 'Caixa de Barcelona'. 


\section{LITERATURE CITED}

Adiyodi, R. (1985). Reproduction and its control. In: Bliss, D. E., Mantel, L. H. (eds.) The biology of Crustacea, Vol. 9, Integument, pigments and hormonal processes. Academic Press, New York, p. 147-215

Aiken, D. E., Waddy, S. L. (1980). Reproductive biology. In: Cobb, J. S., Phillips, B. S. (eds.) The biology and management of lobsters, Vol. I, Physiology and behavior. Academic Press, New York, p. 215-276

Aquacop (1975). Maturation and spawning in captivity of penaeid prawns Penaeus merguiensis De Man, Penaeus japonicus Bate, Penaeus aztecus Ives, Metapenaeus ensis (De Haan) and Penaeus semisulcatus De Haan. In: Avault, J. W. (ed.) Proc. World Maricul. Soc. 6. Baton Rouge, p. $123-132$

Arrobas, I., Ribeiro Cascalho, A. (1987). On the biology and fishery of Aristeus antennatus (Risso, 1816) in the south Portuguese coast. Investigación Pesq. 51 (Supl. 1): 233-243

Beninger, P. G., Elner, R. W., Foyle, T. P., Odense, P. H. (1988). Functional anatomy of the male reproductive system and the female spermatheca in the snow crab Chionoecetes opilio (O. Fabricius) (Decapoda: Majidae) and a hypothesis for fertilization. J. Crust. Biol. 8: 322-332

Burukovsky, R. N. (1978). On the biology of the shrimp Aristeus varidens. Biol. Morya, Vladivostok 3: 70-77

Cartes, J. E., Sardà, F. (1989). Feeding ecology of the deepwater aristeid crustacean Aristeus antennatus. Mar. Ecol. Prog. Ser. 54: 229-238

Chow, S. (1989). Homologous functional structure and origin of the spermatophores in six palaemonid shrimps (Decapoda, Caridea). Crustaceana 57: 247-252

Chow, S., Dougherty, M. M., Dougherty, W. J., Sandifer, P. A. (1991). Spermatophore formation in the white shrimps Penaeus setiferus and $P$. vannamei. J. Crust. Biol. 11: 201-216

Clark, W. H. Jr, Yudin, A. I., Griffin, F. J., Shigekawa, K. (1984). The control of gamete activation and fertilization in the marine Penaeidae, Sicyonia ingentis. In: Engels, W. Clark, W. H., Jr, Fischer, A., Olive, P. J. W., Went, D. F. (eds.) Advances in invertebrate reproduction, Vol. 3. Elsevier North Holland, Amsterdam, p. 459-472

Cummings, W. C. (1961). Maturation and spawning of the pink shrimp, Penaeus duorarum Burkenroad. Trans. Am. Fish. Soc. 90 : $462-468$

Dall, W. (1991). Zoogeography of the Penaeidae. Mem. Qd Mus. 31: 39-50

Dall, W., Hill, B. J., Rothlisberg, P. C., Sharples, D. J. (1990). The biology of the Pennaeidae. In: Blaxter, J. H. S., Southward, A. J. (eds.) Advances in marine biology, Vol. 27. Academic Press, New York, p. 1-489

De Freitas. A. J. (1985). The Penaeoidea of southeast Africa. II The families Aristeidae and Solenoceridae. Investl Rep. Oceanogr. Res. Inst. S. Afr. Ass. mar. Biol. Res. 57: 1-69

Demestre, M. (1990). Biología pesquera de la gamba Aristeus antennatus (Risso, 1816) en el mar Catalán. Ph.D. thesis, Univ. Barcelona

Diesel, R. (1989). Structure and function of the reproductive system of the symbiotic spider crab Inachus phalangium (Decapoda: Majidae): observations on sperm transfer, sperm storage, and spawning. J. Crust. Biol. 9: 266-277

Dougherty, W. J., Dougherty, M. M. (1989). Electron microscopical and histochemical observations on melanized sperm and spermatophores of pond-cultured shrimp, Penaeus vannamei. J. Invert. Pathol. 54: 331-343

Dougherty, W. J., Dougherty, M. M., Harris, S. G. (1986). Ultrastructural and histochemical observations on electro- ejaculated spermatophores of the palaemonid shrimp. Macrobrachium rosenbergii. Tissue. Cell 18: 709-724

Durfort, M. (1978). Un método de tinción policrómico de uso rápido. Misc. Zool. 4: 205-210

Durfort, M., Bozzo, M. G., Poquet, M. (1985). Fine structure of the deferent duct and the seminal vesicle of Diaptomus conexus (Crustacea: Decapoda). Bull. Inst. Cat. Hist. Nat. 52(Sec. Zool. 6): 103-117

Emmerson, W. D. (1980). Induced maturation of prawn Penaeus indicus. Mar. Ecol. Prog. Ser. 2: 121-131

Felgenhauer, B. E. (1987). Techniques for preparing crustaceans for scanning electron microscopy. J. Crust. Biol. 7: $71-76$

García Valero. J. (1988). La gametogènesi de Acanthocyclops robustus G. O. Sars (Crustacea, Copepoda). Estudi ultrastructural. Ph.D. thesis, Univ. Barcelona

Genthe, H. C. Jr (1969). The reproductive biology of the Sergestes similis (Decapoda, Natantia). Mar. Biol. 2: $203-217$

Gosàlbez, J., López-Fuster, M. J., Durfort, M. (1979). Ein neues Färbungsverfahren für Hodenzellen von Kleinsäugetieren. Sonderdruck aus 'Säugetierkundliche Mitteilungen' BLV Verlag. München 40: 303-305

Hartnoll, R. G. (1969). Mating in the Brachyura. Crustaceana 16: $161-181$

Heldt, J. H. (1932). Sur la fécondation chez la crevette rose du large (Parapenaeus longirostris Lucas). C.r. Acad. Sci., Paris 185: 2161-2163

Heldt, J H. (1938). De l'appareil génital des Penaeidae. Relations morphologiques entre spermatophore, thelycum et petasma. Trav. Stn Zool. Wimereux 13: 349-358

Jamieson, B. G. M. (1991). Ultrastructure and phylogeny of crustacean spermatozoa. Mem. Qd Mus. 31: 109-142

Johnson, P. T. (1980). Histology of the blue crab Callinectes sapidus. A model for the Decapoda. Praeger Publishers, New York

King, J. E. (1948). A study of the reproductive organs of the common marine shrimp, Penaeus setiferus (L.). Biol. Bull. 94: $244-262$

Kleve, M. G., Yudin, A. I., Clark, W. H., Jr (1980). Fine structure of the unistellate sperm of the shrimp. Sicyonia ingentis (Natantia). Tissue Cell 12: 29-45

Malek, S. R. A., Bawab, F. M. (1974a). The formation of the spermatophore in Penaeus kerathurus (Forskall, 1775) (Decapoda, Penaeidae). II. The deposition of the layers of the body and of the wing. Crustaceana 27: 73-83

Malek, S. R. A., Bawab, F. M. (1974b). The formation of the spermatophore in Penaeus kerathurus (Forskal, 1775) (Decapoda, Penaeidae). I. The initial formation of a sperm mass. Crustaceana 26: 273-285

Orsi Relini, L., Tunesi, L. (1987). The structure of the spermatophore in Aristeus antennatus (Risso, 1816). lnvestigación Pesq. 51(Supl. 1): 461-470

Palombi, A. (1939). Note biologiche sui Peneidi. La fecondazione e la deposizione delle uova in Eusicyonia carinata (Olivi). Boll. Zool. 10: 223-227

Pérez Farfante, 1. (1969). Western Atlantic shrimps of the genus Penaeus. Fish. Bull. U.S. 67: 461-591

Pérez Farfante, I. (1975). Spermatophores and thelyca of the american white shrimp, genus Penaeus, subgenus Litopenaeus. Fish. Bull. U.S. 73: 463-486

Pérez Farfante, I. (1988). Illustrated key to penaeoid shrimps of commerce in the Americas. NOAA Tech. Rep. NMFS 64: $1-32$

Plllai, M. C., Clark, W. H., Jr (1987). Oocyte activation in the marine shrimp, Sicyonia ingentis. J. exp. Zool. 244: $325-330$ 
Pochon-Masson, J. (1983). Arthropoda-Crustacea. In: Adiyodi, K. G., Adiyodi, R. G. (eds.) Reproductive biology of invertebrates, Vol. II, Spermatogenesis and sperm function. Wiley \& Sons, Chichester, p. 407-449

Primavera, J. H. (1979). Notes on the courtship and mating behavior in Penaeus monodon Fabricius (Decapoda, Natantia). Crustaceana 37: 287-292

Relini Orsi, L., Relini, G. (1979). Pesca e riprodozione del gambero rosso Aristeus antennatus (Decapoda, Penaeidae) nel Mar Ligure. Quad. Civica Staz. Idrobiol. Milano 7: 39

Sardà, F., Demestre, M. (1987). Estudio biológico de la gamba Aristeus antennatus (Risso, 1816) en el Mar Catalán (NE de España). Investigación Pesq. 51(Supl.1): 213-232

Sardà, F., Demestre, M. (1989). Shortening of the rostrum and rostral variability in Aristeus antennatus (Risso, 1816) (Decapoda: Aristeidae). J. Crust. Biol. 9: 570-577

This article was submitted to the editor
Schaller, F. (1979). Significance of sperm transfer and formation of spermatophores in Arthropod phylogeny. In: Gupta, A. P. (ed.) Arthropod phylogeny. IV. Anatomy, morphology, and physiology. van Nostrand Reinhold Company, New York, p. 587-608

Talbot, P., Summers, R. G. (1978). The structure of sperm from Panulirus, the spiny lobster, with special regard to the acrosome. J. Ultrastruct. Res. 64: 341-351

Tirmizi, N. M. (1968). On the structure and some developmental stages of genitalia in the prawn Parapenaeopsis stylifera ( $\mathrm{H}$. Milne Edwards) (Decapoda, Penaeidea). Crustaceana 15: 193-203

Tuma, D. J. (1967). A description of the development of primary and secondary sexual characters in the banana prawn, Penaeus merguiensis De Man (Crustacea: Decapoda: Penaeidae). Aust. J. mar. Freshwat. Res. 18: 73-88

Manuscript first received: January 27, 1992

Revised version accepted: May 18, 1992 